\title{
Wage Determination under Plan and Early Transition: Bulgarian Evidence using Matched Employer-Employee Data.
}

by

\section{Derek C. Jones*}

and

\section{Kosali Ilayperuma Simon**}

\section{Abstract}

September 2004

By using a large panel containing matching employer-employee information, noncompetitive forces are found to dominate wage determination during planning. During early transition the process becomes much more market driven, though a significant role remains for other factors. The preferred specifications are not baseline models restricted to conventional dimensions of human capital, but always include firm-and person- specific fixed effects and other firm and individual attributes. Depending on the particular specification, returns to education at least double during transition and the significance of human capital variables is insensitive to the inclusion of firm effects. However, findings for other variables are sensitive to specifications that do or do not include firm effects as well as person effects.

* Department of Economics, Hamilton College, Clinton, New York 13323. **Department of Policy Analysis and Management, Cornell University, Ithaca, NY 14850 and NBER. Jones acknowledges support from NSF SES 9223359, the National Council for Eastern European and Eurasian Studies and the Bulgarian Ministry of Science and Higher Education. Simon acknowledges a Thomas J. Watson Fellowship for interview-based research in Bulgaria during 1995. The paper has benefited from comments from Jeffrey Pliskin and an anonymous referee. 


\section{Introduction.}

A key issue that has attracted much attention concerning labor markets in transition economies is the determinants of earnings (e.g Bird and Wagner, 1994; Brainerd, 1998; Campos and Jolliffe, 2003; Fleischer, et al. 2003; Newell and Reilly, 1999) with that literature identifying the existence of sizeable returns to education. By contrast, the econometrics literature that examines similar matters during the command era is not only much slimmer but also seldom finds persuasive evidence of the existence of returns to education. Taken together, however, the findings derived from these two literatures point to substantial change in the operation of labor markets during early transition. Nonetheless, before accepting the conclusion that education is of greater consequence for earnings in these economies than in the past, it is important to realize that most studies, especially those that estimate basic Mincer earnings regressions, may be limited in important respects by the nature and scope of the underlying data (Heckman, Lochner and Todd, 2003).

First, most studies are limited in the range of information that is available on individual characteristics. ${ }^{1}$ In addition, few studies of transition have been able to give sufficient attention to the potentially important role in wage determination that is played by factors that are exogenous to individuals, including huge differences in enterprise performance (Aghion et al., 1994). Second, studies in this area have rarely used data on employees matched with data on employers. This is an important omission because recent advances in the economic analysis of labor markets elsewhere find that estimates derived from matched employee-employer data sets (for example, on returns to education) are often substantially different than findings based on more restricted data (e.g. Abowd and Kramarz, 1998.) 
In this paper, we respond to the shortcomings of much of the available literature and use a unique data set -- for a large sample of employees with corresponding information for Bulgarian firms during both the command and early transition eras. Using this matched employer-employee data enables us to test a wide range of hypotheses on the determinants of wages for a planned economy as well as during early transition. By estimating diverse specifications, including estimates with random effects/clustering based on person, and fixed firm effects, we are able to rigorously examine the impact of education on earnings including separate specifications for the fading days of communism and early transition. ${ }^{2}$ In addition, our rich data on individuals allows us to take into account individual characteristic whose exclusion in previous work may also lead to overestimates of the impact of education on earnings. Since Bulgaria shares many characteristics with other former communist countries (e.g., in the past, remarkable centralization and limited contact with the west), arguably our findings may have more general applicability than some other studies.

We continue by assessing the relative importance of competitive and non-competitive explanations for wage determination under plan and market. We also examine the potential influence on wage determination of diverse factors, such as firm performance during the two regimes. Reflecting a major theme in the transition literature, particular attention is given to the role of human capital factors. In the main section, after discussing our empirical strategy, we present and examine our results. Finally, some implications of the findings are considered. 


\section{Conceptual and Institutional Framework}

As in other command economies, diverse institutional arrangements implied that the process of wage determination was probably dominated by non-market forces during the latter days of planning in Bulgaria. As was the norm in a Soviet type economy (STE), the formal structures and processes governing the determination of compensation in Bulgaria were very centralized. $^{3}$ In this centrally regulated framework, wages played no fundamental allocative role and, at the level of the firm, were set on the basis of recommendations and standards sent from above. In addition, the state sector comprised a small number of huge firms (Jones and Parvulov, 1995), which accounted for 93.5\% of total employment (with the bulk of the remainder in the so-called "cooperative" sector). Firms had no risk of bankruptcy and operated within a context of soft budget constraints (Kornai, 1990). Managers of state enterprises were essentially agents of government economic ministries whose objective was to implement the plan with all major decisions (including wage setting) determined by the state (Ellman, 1989).

Hence, in accounting for variation in earnings across employees during planning, we hypothesize that the wage determination process would be influenced overwhelmingly by noncompetitive forces. These forces would operate through various channels including at industry, firm and regional levels. Thus, reflecting the preferred Stalinist model of development (and a bias towards heavy industry), we would expect that there would be industry wage effects. In addition, coalitions of managers and workers would be expected to be especially strong in the very biggest firms. Their political influence would be expected to translate into a firm size wage premium. By contrast, for workers in smaller firms in those sectors valued less by planners’ Marxist ideology (e.g. light industry and cooperatively owned firms), budget constraints were apt to be tighter and political influences on wages weaker. Wages in those sectors tended to be the 
lowest in smaller firms, especially those in light industry, trade, agriculture and public services. In the main, the administered nature of the economy in 1989 would mean that regional differences in earnings would not be expected to be very important.

At the same time, those competitive factors that are usually stressed in capitalist systems, notably individual differences in human capital, are hypothesized not to play a large role in accounting for wage differences during planning. This is not to say that human capital factors played no role. In fact, during the planning period in view of the prevailing ideology and values, the role of human capital type variables was ambiguous (Flanagan, 1994). While there was a strong predisposition towards egalitarian wages, factors including skill, work experience, and education supposedly influenced pay determination (Rubin, 1986). For several reasons, including considerations of allocative efficiency, it was unlikely that the process of wage determination would have ignored the role of these variables (Atkinson and Micklewright, 1992). Thus Bergson (1988:84) observes that in STEs workers were grouped by type of work performed, and that several aspects of the job mattered, including "...its complexities, the responsibilities involved, and other aspects delineating skill..." (emphasis added). Also, with workers free to change jobs and labor markets characterized by excess demand, planners might have been expected to reward investments in human capital (Rutkowski, 1994). In addition, to try to reduce labor turnover, many reforming socialist countries introduced bonus schemes that rewarded years of uninterrupted service (firm specific experience). However, human capital type variables would not be expected to be of major importance in accounting for earnings differences. Rather, wages would be centrally fixed to reflect other factors so that employees in more skilled occupations might receive lower wages than workers who were engaged in especially arduous or unhealthy work. 
In addition, the role of other differences in individual attributes such as gender might be expected to play a modest role in influencing wages during communism. In large part this follows the dominant ideology which called both for very high participation rates in the laborforce by all able-bodied adults and for wage patterns such that pronounced earnings differences due to gender would not exist under communism. There is nonetheless anecdotal evidence (e.g. Beleva et al., 1995) that discrimination was in fact widespread in Eastern Europe

By 1992 major systemic reforms had begun as the Bulgarian economy searched for an acceptable form of a market economy. Major steps towards the introduction of a market economy began in February 1991 with a program that freed prices, allowed the exchange rate to float, greatly reduced state subsidies, gave firms decision-making authority regarding pricing, investment, employment and production decisions, and de-emphasized sectors traditionally favored, notably heavy industries (Jones and Miller, ed., 1995.) As part of this reform program a wage stabilization plan was introduced. Overall wage growth during this period was limited to $45 \%$ in the first quarter of 1991 , substantially less than inflation with prices rising about $225 \%$ in the two months following the February 1991 reform program. As part of the process of introducing new institutional arrangements, a tripartite commission was created at the national level with representatives from employers, unions and the government. Under this income policy (Bogetic and Fox, 1993) wage negotiations took place at national, firm, and individual levels. The national level involved negotiations on issues such as minimum wages, while industry minima were negotiated at industry level. At the firm level, a new and more decentralized system of wage determination took effect in July 1991. Under this plan, firms could decide the relative wages given to their employees, as long as the total wage bill was restrained. If firms let 
their wage bill increase by more than a stipulated amount, which varied according to previous overall inflation, productivity and the average wage, a punitive tax (up to 400\%) was imposed.

Hence, we hypothesize that in wage determination during early transition those factors that are usually stressed in explanations of wage determination in capitalist systems would be expected to play a bigger role. The introduction of a more decentralized system of wage setting allows for more say by autonomous managers, and hence a bigger role for productivity type variables that are connected with individual workers' characteristics. However, while the human capital model would be expected to become more pertinent, not all formal characteristics would be expected to be valued in the emerging marketplace. Thus in this framework while formal educational qualifications might be expected to exert a greater effect on individuals' wages, under competitive conditions the returns from work experience gained under the old regime would be expected to have been devalued.

By 1992 while we predict that a substantial part in the wage determination process would continue to be played by non-competitive forces, we expect that those particular influences would be quite different than during the command era. Prominent factors include the different speed at which differently placed and differently managed firms would be expected to adjust to a changing environment, leading to the co-existence of firms with substantial differences in performance across and within sectors (Pinto et al. 1993). We would also expect the slow development of the Bulgarian private sector (especially in manufacturing industry, Jones and Rock, 1994) to have a less dramatic influence on the evolution of wage differences in state firms than in countries where the private sector has flourished.

In addition, during early transition, we hypothesize that other firm level effects on earnings would be expected to have emerged in Bulgaria. In a world with imperfectly 
competitive markets, such effects will potentially reflect several competitive and noncompetitive factors including differences in managerial quality, product market concentration and access to other resources, especially capital. Moreover, by 1992, with firm restructuring and substantial downsizing underway, efficiency wages theory might lead one to expect firm size effects. To overcome potential inefficiencies of size --it is argued that intra firm coordination and cooperation breaks down as firm size increases and that working in huge establishments may foster alienation and possibly sabotage--employers in large firms may choose to pay workers above the competitive rate. In turn, this increases worker efforts and leads to less need for supervision (Krueger and Summers, 1988.)

Various theoretical frameworks have been developed that predict the existence of discrimination by gender and race for a market system (for reviews, see Gunderson, 1989.) Hence, for an economy in transition, as market forces begin to take hold, without countervailing measures (such as the introduction and effective implementation of strong anti-discrimination laws), gender differentials might arguably be expected to emerge. Much of the apparent gap in earnings for women could however be attributed to structural changes reflecting differences in starting conditions, notably the fact that women were under-represented in managerial or skilled occupations (and over-represented in positions where the employment surplus is greatest, such as lower administrative positions).

By 1992 we would also expect that the varying impact of the reform process on different industries and different regions would begin to give rise to regional and sectoral differences in earnings. These changes were probably closely connected to competitive conditions, especially changes in product and local labor markets. The relative fall in earnings would therefore be expected to be most severe in industries suffering the most serious falls in output. These 
occurred in the first half of 1992, and were especially evident in food processing, mechanical, ${ }^{4}$ chemical and electrical engineering, chemicals, and least of all in non-ferrous metals (A.E.C.D., 1993). Regional differences might also be expected to become quite significant in the wage determination process. Unemployment rates began to differ in local labor markets and would be expected to have effects on individual earnings. To test these hypotheses it is important to examine for both years for the effect of sectoral and regional differences on individuals' wages. It is important to note that since we include firm level fixed effects in our empirical specifications, all these effects are eventually subsumed in the different intercept terms so we would be able to control for them, but not comment on the relative importance of each factor.

During early transition, there were changes in the pattern of preferred forms of payment (ILO, 1993). Given the crucial importance of the incentives issue for economies plagued by low productivity, and in view of the substantial body of work that argues that the form of the compensation system affects the level of compensation too (e.g. Lewin, Mitchell and Zaidi, 1995), we hypothesize that these changes have had some market logic. Specifically we expect that workers receiving bonus payments will have higher earnings.

\section{Data and Empirical Strategy}

Our estimates are based on what is perhaps the first data base for a transition economy that includes rich data for individuals and matching information for diverse characteristics at the firm level. The data we analyze are from several related sources. Fundamentally the data are for firms originally selected for a project sponsored by the ILO to assess microeconomic changes in labor practices in Bulgarian industry. The survey involved 490 establishments, selected to ensure a nationally and sectorally representative sample. Specifically, the population was 
defined as all state-owned (in 1989) Bulgarian manufacturing organizations (SOE's) that operated on a for-profit basis and had more than 80 employees in 1992, the year of the first wave of data collection. For these firms we collected various economic and financial data. Importantly, our data constitute a panel and are also quite rich in important respects. For example, we are able to construct different measures of key variables such as "enterprise performance”. This is potentially important in enabling us to respond both to the well-known problems surrounding the appropriate way to measure these crucial variables and to the difficulties that might emerge because of concerns associated with the reliability of accounting information in transition countries. We collected the data so that they would span both the last years of communism and early transition. Also, when sampled establishments by industry are compared with the country-wide population by employment shares per industry, in general the sample closely reproduces the population distribution.

Data on individuals are from a sub-sample of randomly chosen establishments. The sampling design for individuals establishes a sampling floor of at least 10 employees per establishment with the probability of inclusion declining with the size of the establishment. The primary interest was in achieving at least minimally reliable average data per establishment rather than a random sample of the employed labor force in manufacturing firms.

While Appendix A provides definitions of variables, in Table 1 we report the means of variables used in our empirical work. Since in most of our empirical work we estimate regressions separately for early transition (1991-1992) and late communism (1989-1990) descriptive statistics are reported separately for those periods.

In examining some of the descriptive statistics reported, we note that privatization was delayed in Bulgaria and that the overwhelming bulk of firms continued to be state owned during 
both periods. However, reflecting the impact of transition to the market, we also see that firm performance increased markedly during early transition (and when compared with fading communism.) In terms of human capital we see that the average Bulgarian worker had about 12 years of education ${ }^{5}$ and, during the early period, about 18 years of experience in the labor market. The highest proportion of workers worked in Sofia and Pleven while the least (about 11\%) worked in Pernik. Table 1 also contains information on other individual characteristics. Thus we see that $84-85 \%$ of workers were married while $41 \%$ are men.

Our empirical approach reflects our central interest in examining the role of human capital variables, in understanding their importance during fading planning as opposed to early transition, and in identifying the sensitivity of these findings to the inclusion of other controls, especially those associated with particular firms. To this end we estimate two sets of regressions. We begin by estimating a series of basic, baseline Mincerian-type earnings equations. In this first set of regressions, we include standard proxies for individual specific characteristics of interest-e.g. education and experience. Specifically we follow the literature that suggests that linearity in schooling is a pretty good measure of education (e.g. Heckman and Polachek,1974) and include a linear measure for years of education. ${ }^{6}$ Since human capital theory suggests that earnings generally should follow a parabolic shape, reaching a maximum somewhere in mid-life, we include variables in the estimated earnings equation that are quadratic in total labor market experience. ${ }^{7}$ In these baseline models, we report robust standard errors based on clustering at the individual level. Our results were virtually identical when we used person random fixed effects instead. ${ }^{8}$ These baseline models also include controls for time. In the first model, since we use pooled data (i.e. for 1989-1992), we enter three time dummies. In the two remaining 
specifications we focus on issues of "plan versus market" and split the data by time period according to whether the time corresponds to a period of planning or early transition. ${ }^{9}$

For several reasons, estimates that are based on basic Mincer regressions (as reported in Table 2) must be treated with caution, especially when considering policy implications for education and employment. As Heckman et al. (2003) noted, in order to assume that reliable estimates of returns to education have been identified, it is necessary to assume an unchanging economic environment. While this is always a demanding requirement, it is especially so during times of transition in the former communist countries! There are some steps, however, that one can undertake to improve the reliability of estimates of the returns to education and, in remaining regressions, we begin to respond to some of the well-known problems involved in the baseline specifications. We proceed in two steps.

In the first stage we augment the baseline specification with additional individual and (time varying) firm characteristics; perhaps the most important individual attribute we have is gender which enables us to test hypotheses concerning the possible existence of gender discrimination. Our data also enable us to take into account two other individual attributes, marital status and form of compensation. ${ }^{10}$ The principal firm characteristic for which we have information is enterprise performance. While the available data enable us to use various measures, in the reported estimates we use profitability per worker. ${ }^{11}$ Reflecting the enormous attention that enterprise ownership and the firm's competitive environment have attracted (e.g. Djankov and Murrell, 2002), we also include a dummy for state ownership and a measure of market share. Finally, we also consider the role of enterprise size. In order to check whether our estimates are compromised by workers self-selecting into different firms (e.g. based on 
ownership), we also examined the mobility of individuals in the sample. We find strong evidence of immobility. ${ }^{12}$

In the second stage we make full use of the matched employer-employee data and examine whether our findings are sensitive to the inclusion of firm specific effects (as well as person fixed effects.) Our discussion of wage determination in the Conceptual and Institutional Framework referred to many factors for which we do not directly control (e.g. industry and union) when including firm fixed effects, because they do not change in our panel. While inclusion of both firm and person fixed effects may be the most rigorous method of isolating the returns to human capital, we cannot do so in this context because of the specific human capital factor we focus on, education. In a sample of workers continuously employed by the same firm (as in our sample), there is often little or no change in formal education. Thus, we either include person random effects or correct standard errors to account for the fact that multiple observations for the same individual have errors that are correlated in an arbitrary fashion.

\section{Findings}

We begin by first discussing findings for our baseline Mincerian-type equations (Table 2.) First, we consider the findings for the model reported in the first column, (Model 1) which uses data for the whole time period, 1989-1992. In this specification we cluster at the person level to take into account the correlation of the disturbance terms of multiple observations on the same person. ${ }^{13}$ In this baseline model we find that the linear measure of education is strongly statistically significant and that the returns to a year of education are estimated to be almost $4 \%$. An F test on the joint significance of the experience variables rejects the hypothesis that experience does not affect wage determination (even though the quadratic in experience itself is 
not statistically significant.) ${ }^{14}$ However, the effect of experience is apparently quite small since, when evaluated at the mean level of experience of about 11 years, the experience coefficients imply that one more year of experience increases wages by about $1 \% .^{15}$

In columns (2) and (3) of Table 2, we consider the wage determination process as it works during fading planning as opposed to early transition. We number the new models consecutively, with 'a' and 'b’ versions to denote runs with 1989-1990 data vs. 1991-1992 data respectively. As predicted, we find that Chow tests strongly reject the hypothesis that coefficients are equal across time in specifications with and without firm fixed effects and person level clustering (and thus in all subsequent regressions we will estimate regressions for the two time periods separately.) The clear finding that emerges from these models (which also include person clusters and the appropriate time dummies) is that human capital variables are much more important during early transition than during planning. During early transition, we find that the returns to a year of education are $5.4 \%$ which is quite a bit higher than when the whole time period was used. Moreover, they contrast sharply with the education coefficients during planning which indicate that the returns to a year of education were less than $2 \%$ during the period of fading communism. However for experience the story is different (though essentially unchanged from findings based on the pooled estimates.) During both periods the effect of experience appears to be quite small (though statistically significant based on F tests), and the quadratic in experience remains statistically insignificant. There is little support for the hypothesis that transition has led to devaluation of firm-specific skills acquired during communism. Thus during both planning and early transition the returns to experience appear to be broadly comparable.

In Table 3 we again make use of the unusual feature of our data set -the availability of data on matched employees and employers-- and report findings from models that include 
information for several individual and firm attributes. Models 3a and 3b are thus similar to Models 2a and 2b except that seven additional variables have been added to test hypotheses concerning firm and individual characteristics other than proxies for human capital. A key finding is that the preferred specifications are not baseline models restricted to conventional dimensions of human capital (and person- specific effects), but are always these augmented specifications which include other firm and individual attributes. ${ }^{16}$

At the same time, another important finding is that controlling for these other variables has only a modest impact on the returns to education. In addition, returns to education continue to be far higher during early transition compared to the planning period. Moreover, in both periods, both experience and its squared terms are now significant, whereas earlier only the linear term was. The magnitude of the linear term is somewhat larger than it was previously (up to $1.6 \%$ compared to a maximum of $1.2 \%$ before). The coefficients imply that the effect of experience is non linear, reaching a maximum at 30 years with the firm in the period before reform and 35 years in the early transition period.

Besides these conventional measures of human capital Table 3 reports findings on the impact of three other individual attributes namely gender (Male), the form of compensation (Salary) and marital status (Married). Together these individual characteristics have a significant impact on earnings, both economically and statistically. ${ }^{17}$ In both periods we see that, other things equal, men (Male) are paid more. In addition the effect is large, between 15 and 25\%. Perhaps surprisingly, the impact is strongest during the planning era—early transition has been accompanied by a fall in the magnitude of the coefficient measuring the extent of gender discrimination (though at 15\% it still remains large.) Our findings also indicate that the form of the compensation system (Salary), and whether or not the worker receives performance-related 
pay, is a significant determinant of pay. However, whereas under planning workers on fixed pay earned $12 \%$ less, other things equal, during early transition employees with fixed wage payment systems (Salary) earned 14\% more than those with a variable component in pay. One interpretation of this pattern is that this is one way in which those employees receiving incentive pay are more vulnerable. Marital status (Married) is not found to affect the wage determination process in either period.

Table 3 also includes findings for four firm characteristics, namely: enterprise performance (Profit per worker), Firm Size, Market share and enterprise ownership (State owned). An F test on the joint significance of these firm attributes rejects the hypothesis that firm characteristics do not affect wage determination. ${ }^{18}$ Several individual firm-level variables are found to play important roles in the wage determination process. Thus profitability is found to have statistically significant positive effects on earnings in both periods. The impact of enterprise performance on individual earnings is actually found to be larger during the planning period. ${ }^{19}$ Our findings also point to some interesting effects of firm size on earnings. Whereas during the early period there is no evidence that employees benefit as firms grow in size, during early transition we find that employees in bigger firms benefit modestly. Surprisingly, during fading communism this specification points to the existence of an impact of market share on individual earnings. However, during early transition our findings point to the strengthening of this relationship. Finally, we uncover evidence of a hypothesized link between enterprise ownership and earnings. Moreover we find evidence for both the planning period as well as early transition that state ownership has a positive impact on individual earnings. Workers in firms that are stateowned receive a premium over other employees in our sample, who worked mainly in cooperatives (rather than in private firms). This finding is consistent with the hypothesis that 
during both periods, state-owned firms continued to face softer budget constraints than other firms with, for example, state owned firms always enjoying easier access to inter-enterprise credits during the period of study than other firms.

Finally, we consider the sensitivity of our findings reported in Table 3 to the inclusion of firm fixed effects. When the specifications reported in Table 3 are estimated with firm effects, we see that the preferred specification is always as reported in Table 4. In other words the preferred specifications are neither baseline models restricted to conventional dimensions of human capital and person-specific effects (Table 2), nor baseline models augmented to include other firm and individual attributes (Table 3), but baseline models augmented to include both firm and individual attributes and firm-effects.

Importantly, however, the size and the significance of human capital variables are insensitive to the inclusion of firm effects. The basic story remains unchanged with returns to education approximately doubling during early transition and the impact of experience continuing to play a statistically significant though economically modest role.

The same can be said concerning the role played by other (non-human capital) regressors. Compared to findings reported in Table 3 we see that the addition of firm effects frequently is associated with large changes in both the size and the direction of the coefficients for several firm and individual characteristics. For example, for both periods the omission of firm effects (Table 3) leads to workers in state owned firms apparently receiving a sizeable wage premium (12\% during planning, and rising to 22\% during early transition). But in the preferred specifications reported in Table 4, state ownership is found to have no statistically significant effect on earnings. This finding is consistent with the hypothesis that during both periods all 
firms were facing similar budget constraints, and that, for example, one type of firm had easier access to inter-enterprise credits during the period of study than other firms.

Concerning firm size, from the preferred specification (Table 4) we see that during transition employees in larger firms received lower earnings, other things equal, while during planning, size did not matter. This pattern is thus consistent with the hypothesis that wages are reflecting firms coming to terms with the existence of overstaffing during early transition and that it is workers in the downsizing firms that fare better. As such these findings strongly differ from those reported in Table 3 and which did not take account of firm effects.

The findings reported in Table 4 also reveal that while men earn more than do women the size of the gender premium is rather less than appears from Table 3. For example, during early transition, on average men earn about 9\% more than do women, compared to the earlier estimates of about 15\% (Table 3). Also the introduction of firm-effects is found to overturn the surprising finding reported in Table 3 that market share mattered for earnings during fading communism.

\section{Conclusions and Implications}

Using a new and most unusual data set on individuals and matching information on firms, the determinants of earnings during plan and early market in Bulgaria are examined. Consistent with our hypotheses and the observed changes in the legal, institutional and economic environment, we find strong evidence that the factors determining wages changed significantly during early transition. Whereas during planning non-competitive forces dominate wage determination, during early transition the process becomes more market driven, though a significant role also exists for non-competitive and disequilibrium forces. Baseline models 
restricted to orthodox dimensions of human capital are not the preferred specifications when describing the wage determination process. We also find that our preferred specifications are estimated using variables drawn from our matched employer-employee data and including firm specific effects. While findings on the importance of human capital variables typically are insensitive to the inclusion of firm effects, this is not the case for other variables that are found to play important roles in wage determination during transition.

During the centralized years we find evidence of modest returns to education and experience; during early transition we find evidence of much larger returns to education and evidence that returns to firm-level experience persist. Differences in earnings by gender persist, though they have fallen. A growing role for market-related characteristics is reflected in the mergence of a positive relationship between wages and an enterprise's share of the market and a declining role for firm size, though no evidence of link between enterprise performance and earnings during transition is found .

These findings imply that both individual characteristics that reflect productivity as well as firm characteristics that capture diverse factors that bear on enterprise performance, are playing bigger roles in the evolving wage determination process. Also, the pattern of industrial wage effects has responded to the changed imperatives of the restructuring economy. As such, these changes are consistent with the hypothesis that, even absent privatization, an important degree of change is possible in economies in transition. That is, the change in the forces determining individual incomes is consistent with the hypothesis that independent managers operating in more competitive contexts, with price liberalization and a growing private sector, increasingly are making decisions that have a market logic. 
However, the findings also imply that the wage determination process in Bulgaria in 1992 was far from being completely market driven and that non-competitive factors always were powerful. For example, the findings of lower earnings for women point to the important role played by non-market forces.

There are some interesting similarities and differences in our findings compared to those for other transition economies. As in other country-specific studies (e.g. Bird et al., 1994; Orazem and Vodipevic, 1994; Chase, 1998; Munich et al., 1999) and as found by Newell and Reilly (1999) in their study of nine transition countries, during transition, returns to education increase. However, in Bulgaria typically these returns to education are lower than elsewhere -compared with those found by Flanagan (1994) for the Czech Republic and with returns exceeding 7\% in Germany and Poland (Rutkowski, 1994). While there are also falling returns to experience, again the changes have been much less abrupt than those reported for other former communist countries. Analogously, while as elsewhere the extent of the earnings loss for being female has fallen, the female penalty remains unusually high. Finally, whereas Bird et al. find that workers in state firms in the former East Germany earn less than workers in other forms of enterprise, in Bulgaria during early transition there is no evidence that state ownership affects the earnings of employees in manufacturing firms.

Some of these differences in findings may reflect the fact that other studies have used only individual or enterprise level data and that other studies are seldom based on data sets that include information on workers' employers. Since they were unable to include matching data and many variables that potentially affect the wage determination process, the findings from these studies may in part not be completely reliable. As has been found in studies for advanced market economies (e.g. Abowd and Kramarz, 1999), our findings provide further evidence of the 
importance of using matching employer-employee data when trying to uncover the causes of variation in pay in transition economies. ${ }^{20}$ In addition, the differences in findings may reflect the fact that change has been slower in Bulgaria and that in 1992 Bulgaria remained an economy that was still quite centralized. This line of argument implies that, over time, the forces affecting wages in Bulgaria will begin to more closely resemble those of transition economies where change has been swifter. ${ }^{21}$

An alternative explanation is that what we are in fact seeing is the emergence of different forms of labor market arrangements existing in quite different contexts in different former communist countries. Accordingly differences in forces affecting wages can be expected to persist rather than converge. ${ }^{22}$ Moreover, in this process, it is possible that wage determination in many former communist countries during early transition will be found to more closely resemble the Bulgarian experience than, for example, that of the Visegrad countries. Factors affecting wage determination in Bulgaria may have more general applicability in part because, during Communism, the Bulgarian economy had many characteristics in common with other former Communist countries, both in Eastern and Central Europe as well as newly independent countries that were formerly in the USSR. These features include: a very centralized economy, giantism in the size-distribution of enterprises, very limited economic contact with the West and enormous dependence on trade and technology transfer with CMEA countries. For countries with such features, even though there are substantial differences in the economic reform packages that have been adopted during early transition, arguably for many reasons (e.g. BenNer, Montias and Neuberger, 1993) the common institutional and organizational heritage may be expected to continue to influence and constrain change in the forces affecting wage setting in ways that are broadly comparable to the Bulgarian experience. 


\section{Table 1: Sample Statistics}

\begin{tabular}{l|cccc}
\multicolumn{1}{c|}{ Years } & \multicolumn{2}{c}{$\mathbf{1 9 8 9 - 1 9 9 0}$} & \multicolumn{2}{c}{$\mathbf{1 9 9 1 - 1 9 9 2}$} \\
\hline \multicolumn{1}{c}{ Variable } & Mean & St Dev & Mean & St Dev \\
Log wages & 5.798074 & .5284347 & 7.142699 & .5112701 \\
Education in years & 12.36018 & 2.444958 & 12.34529 & 2.43567 \\
Experience & 18.19285 & 8.750858 & 19.75931 & 9.00237 \\
Experience2 & 407.538 & 342.8708 & 471.4573 & 384.5759 \\
Male & .4084542 & .4916094 & .4111472 & .4920888 \\
Married & .8536768 & .3534741 & .8387097 & .3678336 \\
Salary & .6015508 & .4896401 & .5974423 & .4904599 \\
Region: Bourgas & .1803402 & .3845186 & .1666349 & .3726851 \\
Pernik & .133067 & .3170069 & .1147165 & .31871 \\
Pleven & 1973487 & .3980475 & .208055 & .4059551 \\
Plovdiv & 1628314 & .369258 & .155564 & .3624761 \\
Sofia & .3461731 & .4758087 & .3550296 & .478568 \\
Industry: Wood related & .068034 & .2518358 & .0799771 & .2712836 \\
Textile & .1410705 & .3481378 & .1353312 & .3421096 \\
Engineering & .2206103 & .41471 & .211109 & .4081345 \\
Electrical & .175588 & .3221252 & .1162436 & .3205474 \\
Chemicals & .0392696 & .1942601 & .0389387 & .1934674 \\
Non metals & .0277639 & .1643162 & .0299676 & .1705141 \\
Mining & .0317659 & .1753981 & .0391296 & .1939218 \\
Industry other & .1790895 & .3834752 & .1916396 & .3936286 \\
State Owned & .9384692 & .2403314 & .9204047 & .2706915 \\
Market Share & 3.060188 & 6.084395 & 2.837347 & 6.670968 \\
Log labor force & 6.598877 & .9289241 & 4.895644 & 1.588647 \\
Profit per worker & 4.601321 & 10.9947 & 31.21943 & 48.2231 \\
Number of observations & 3998 & & 5239 \\
& & & &
\end{tabular}

Note: Industry and region are only shown to describe the sample. They are not used in regressions because of the use of firm fixed effects. The number of observations differs across years due to a) new hires and b) missing data. 
Table 2: Baseline Models

\begin{tabular}{l|ccc} 
& Model 1 & Model 2a & Model 2b \\
\hline Education in years & $0.039^{* * *}$ & $0.019^{* * *}$ & $0.054^{* * *}$ \\
Experience & {$[0.003]$} & {$[0.004]$} & {$[0.004]$} \\
Experience2 & $0.011^{* * *}$ & 0.007 & $0.012^{* * *}$ \\
& {$[0.003]$} & {$[0.004]$} & {$[0.004]$} \\
Year 1989 & -0.0001 & 0 & -0.00012 \\
& {$[0.0001]$} & {$[0.0001]$} & {$[0.00009]$} \\
Year 1990 & $-1.590^{* * *}$ & $-0.317^{* * *}$ & N/a \\
Year 1991 & {$[0.013]$} & {$[0.009]$} & \\
Constant & $-1.272^{* * *}$ & N/a & N/a \\
Observations & {$[0.013]$} & & \\
Adjusted R-squared & $-0.201^{* * *}$ & N/a & $-0.201^{* * *}$ \\
Clustering & {$[0.010]$} & & {$[0.010]$} \\
Fixed effects & $6.584^{* * *}$ & $5.588^{* * *}$ & $6.381^{* * *}$ \\
F-Test: Experience terms=0 & {$[0.051]$} & {$[0.069]$} & {$[0.060]$} \\
Prob $>$ F & 9237 & 3998 & 5239 \\
& 0.66 & 0.11 & 0.1 \\
& Person & Person & Person \\
& None & None & None \\
& 37.137 & 16.175 & 30.236 \\
& 0 & 0 & 0 \\
& & &
\end{tabular}

\section{$\underline{\text { Notes }}$}

1. The standard errors are always estimated so that they are robust to heteroskedasticity and cluster corrected to account for multiple observations on the same worker.

2. Model 1: Basic human capital models on pooled data (all 4 years) with year dummy variables. There are no other explanatory variables.

Model 2a: The same model as Model 1, except the sample consists of observations from 1989 and 1990 only. There are no other explanatory variables.

Model 2b: As above for model 2a, except the data are from 1991 and 1992

3. Robust standard errors in brackets

4. * significant at $10 \%$; ** significant at $5 \%$; *** significant at $1 \%$ 
Table 3: Fully Augmented Specifications without Firm-Fixed Effects

\begin{tabular}{|c|c|c|}
\hline & Model 3a & Model 3b \\
\hline Education in years & $\begin{array}{c}0.024 * * * \\
{[0.004]}\end{array}$ & $\begin{array}{c}0.045^{* * *} \\
{[0.003]}\end{array}$ \\
\hline Experience & $\begin{array}{c}0.012 * * * \\
{[0.004]}\end{array}$ & $\begin{array}{c}0.016^{* * *} \\
{[0.003]}\end{array}$ \\
\hline Experience2 & $\begin{array}{c}-0.0001 \\
{[0.0001]}\end{array}$ & $\begin{array}{c}-0.0002 * * * \\
{[0.0001]}\end{array}$ \\
\hline Male & $\begin{array}{c}0.251 * * * \\
{[0.020]}\end{array}$ & $\begin{array}{c}0.154 * * * \\
{[0.015]}\end{array}$ \\
\hline Profit per worker & $\begin{array}{c}0.0026 * * * \\
{[0.0010]}\end{array}$ & $\begin{array}{c}0.0018 * * * \\
{[0.0002]}\end{array}$ \\
\hline Married & $\begin{array}{c}-0.006 \\
{[0.029]}\end{array}$ & $\begin{array}{c}0.008 \\
{[0.021]}\end{array}$ \\
\hline Salary & $\begin{array}{c}-0.122^{* * *} \\
{[0.022]}\end{array}$ & $\begin{array}{c}0.140 * * * \\
{[0.016]}\end{array}$ \\
\hline State owned & $\begin{array}{c}0.122 * * * \\
{[0.034]}\end{array}$ & $\begin{array}{c}0.202^{* * *} \\
{[0.032]}\end{array}$ \\
\hline Market share & $\begin{array}{c}0.005^{* *} \\
{[0.002]}\end{array}$ & $\begin{array}{c}0.009 * * * \\
{[0.001]}\end{array}$ \\
\hline Log firm size & $\begin{array}{c}0.002 \\
{[0.011]}\end{array}$ & $\begin{array}{c}0.050 * * * \\
{[0.009]}\end{array}$ \\
\hline Year 1989 & $\begin{array}{c}-0.320 * * * \\
{[0.009]}\end{array}$ & N/a \\
\hline Year 1991 & N/a & $\begin{array}{c}-0.288 * * * \\
{[0.025]}\end{array}$ \\
\hline Constant & $\begin{array}{c}5.314 * * * \\
{[0.099]}\end{array}$ & $\begin{array}{c}5.840 * * * \\
{[0.068]}\end{array}$ \\
\hline Observations & 3998 & 5239 \\
\hline Clustering & Person & Person \\
\hline Fixed effects & None & none \\
\hline R-squared & 0.19 & 0.24 \\
\hline F-Test: Experience terms=0 & 16.449 & 37.475 \\
\hline Prob $>$ F & 0 & 0 \\
\hline
\end{tabular}

Notes

1. Standard errors are still clustered at the person level.

2. Model 3a: As above for model 2a, except now includes various firm and individual attributes Model 3b: As above for model 2b, except now includes various firm and individual attributes.

3. Robust standard errors in brackets.

4. * significant at $10 \%$; ** significant at $5 \%$; *** significant at $1 \%$ 
Table 4: Fully Augmented Specifications with Firm-Fixed Effects

\begin{tabular}{|c|c|c|}
\hline & Model 4a & Model 4b \\
\hline Education in years & $\begin{array}{c}0.018 * * * \\
{[0.004]}\end{array}$ & $\begin{array}{c}0.039 * * * \\
{[0.003]}\end{array}$ \\
\hline Experience & $\begin{array}{c}0.016^{* * *} \\
{[0.004]}\end{array}$ & $\begin{array}{c}0.015^{* * *} \\
{[0.002]}\end{array}$ \\
\hline Experience2 & $\begin{array}{c}-0.0003^{* *} \\
{[0.0001]}\end{array}$ & $\begin{array}{c}-0.0002 * * * \\
{[0.0001]}\end{array}$ \\
\hline Male & $\begin{array}{c}0.208 * * * \\
{[0.021]}\end{array}$ & $\begin{array}{c}0.093 * * * \\
{[0.013]}\end{array}$ \\
\hline Profit per worker & $\begin{array}{l}0.0013^{* *} \\
{[0.0006]}\end{array}$ & $\begin{array}{c}0.0002 \\
{[0.0002]}\end{array}$ \\
\hline Married & $\begin{array}{c}0.022 \\
{[0.026]}\end{array}$ & $\begin{array}{c}0.007 \\
{[0.016]}\end{array}$ \\
\hline Salary & $\begin{array}{c}-0.086^{* * *} \\
{[0.023]}\end{array}$ & $\begin{array}{c}0.092 * * * \\
{[0.015]}\end{array}$ \\
\hline State owned & $\begin{array}{c}0.175 \\
{[0.109]}\end{array}$ & $\begin{array}{c}0.063 \\
{[0.083]}\end{array}$ \\
\hline Market share & $\begin{array}{c}-0.001 \\
{[0.003]}\end{array}$ & $\begin{array}{c}0.007^{* * *} * \\
{[0.002]}\end{array}$ \\
\hline Log firm size & $\begin{array}{c}0.077^{*} \\
{[0.043]}\end{array}$ & $\begin{array}{c}-0.108 * * * \\
{[0.037]}\end{array}$ \\
\hline Year 1989 & $\begin{array}{c}-0.323 * * * \\
{[0.010]}\end{array}$ & N/a \\
\hline Year 1991 & N/a & $\begin{array}{c}0.065 \\
{[0.095]}\end{array}$ \\
\hline Constant & $\begin{array}{c}4.816^{* * *} \\
{[0.304]}\end{array}$ & $\begin{array}{c}6.785^{* * *} \\
{[0.160]}\end{array}$ \\
\hline Observations & 3998 & 5239 \\
\hline Clustering & Person & Person \\
\hline Fixed effects & Firm & Firm \\
\hline F-Test: Experience terms $=0$ & 16.205 & 36.668 \\
\hline Prob $>$ F & 0 & 0 \\
\hline R-squared & 0.4 & 0.53 \\
\hline
\end{tabular}

Notes

1 Standard errors are still clustered at the person level.

2. Model 4a: As above for model 3a, except now includes firm-fixed effects Model 4b: As above for model 3b, except now includes firm-fixed effects.

3. Robust standard errors in brackets.

4. * significant at $10 \%$; ** significant at $5 \%$; *** significant at $1 \%$ 


\begin{tabular}{|c|c|}
\hline Variable & Definition of Variable \\
\hline Log wages & Log of monthly wage plus bonus payments, in Bulgarian Lev \\
\hline $\begin{array}{l}\text { Education in } \\
\text { years }\end{array}$ & Numbers of years of education completed (reported by employee). \\
\hline Experience & Number of years of potential experience, calculated as age-6-years of education \\
\hline Experience2 & Square of Experience \\
\hline Male & Dummy variable for male worker \\
\hline Married & Dummy variable for married workers \\
\hline Salary & $\begin{array}{l}\text { Dummy variable for form of payment is salary for fixed time (i.e. hourly). Others are } \\
\text { paid primarily by piece rate or by establishment performance. }\end{array}$ \\
\hline Region & Bourgas, Pleven, Pernik, Plovdiv, Sofia regions \\
\hline Industry & Wood work, textiles, engineering, electrical, chemical, nonmetal, mining, and other \\
\hline State Owned & $\begin{array}{l}\text { Dummy variable indicating ownership structure is state-owned. This could be either } \\
\text { state joint stock or purely state owned. }\end{array}$ \\
\hline Market Share & $\begin{array}{l}\text { Market share percent (created). This is created by totaling sales in a given industry } \\
\text { (where there are } 8 \text { industries) for a given year, and calculating how much of it that } \\
\text { particular establishment is responsible for. }\end{array}$ \\
\hline Log Firm Size & $\begin{array}{l}\text { Log of labor force at establishment. This is the average number of employees at the } \\
\text { establishment during the year. }\end{array}$ \\
\hline $\begin{array}{l}\text { Profit per } \\
\text { worker }\end{array}$ & $\begin{array}{l}\text { This is total establishment profits divided by the number of workers on average at the } \\
\text { establishment during the year. }\end{array}$ \\
\hline y1989..y1992 & Dummy variables for year of observation \\
\hline
\end{tabular}




\section{References}

Abowd, John A. and Francis Kramarz (1999) "The analysis of Labor Markets using Matched Employer-Employee data” Handbook of Labor Economics, v.3, ch. 26, N. Holland.

Abowd, John A. and Francis Kramarz (1998) Econometric Analyses of Linked EmployerEmployee Data” Labour Economics, December.

Agency for Economic Coordination and Development (1993) Annual Report, Sofia.

Aghion, Phillipe. Blanchard, Olivier. and Burgess, Robin. 1994, "The Behavior of State Firms in Eastern Europe, pre Privatization," European Economic Review, 38, 1327-1349

Atkinson, Anthony and John Micklewright (1992) Economic Transformation in Eastern Europe and the Distribution of Income, Cambridge University Press, Cambridge.

Beleva, Iskra, Richard Jackman and Mariela Nenova-Amar (1995) " Bulgaria", in Simon Commander and Fabrizio Coricelli (eds.) Unemployment Restructuring and the labor market in Eastern Europe and Russia, Ch. 5. Washington D.C: The World Bank, pp. 193-232.

Ben-Ner, Avner, Jon Michael Montias and Egon Neuberger (1993) "Basic Issues in Organizations: A Comparative Perspective" J. of Comparative Economics, v. 17, \# 2, June, pp.207-242.

Bergson, Abram (1988) Planning and Performance in Socialist Economies, Unwin Hyman, Boston.

Bird, Edward J., Johannes Schwarze and Gert G. Wagner (1994) "Wage Effects of the Move Towards Free Markets in East Germany" Industrial and Labor Relations Review, v.47, \# 3, pp. 390-400.

Boeri, Tito and Mark Kneese (1992) "Labor Markets and the Transition in Central and Eastern Europe" OECD Economic Studies, \# 18, Spring, pp. 133-163.

Bogetic, Zeljko and Louise Fox (1993) "Incomes Policies During Stabilization: A Review and Some Lessons from Bulgaria and Romania" Comparative Economic Studies

Brainerd, Elizabeth (1998) “Winners and Losers in Russia’s Economic Transition” American Economic Review v 88, \# 5, December, pp. 1098-1116.

Burda, Michael (1993) "Labour Market Adjustment in Eastern Europe" Economic Policy, April, pp. 101-137.

Campos, N. and Jolliffe, D. (2003) “After, Before and During: Returns to education in Hungary 1986-1998” Economic Systems (4), December, pp. 377-390. 
Chase, Robert (1998) "Markets for Communist Human capital: Returns to Education and Experience in the Czech Republic and Slovakia” Industrial and Labor Relations Review, 51 (3): 401-423.

Djankov, Simeon and Peter Murrell, “Enterprise Restructuring in Transition:A Quantitative Survey,” JEL, September 2002.

Ellman, Michael, (1989) Socialist Planning, Cambridge University Press, Cambridge.

Falaris, Evangelos M. (2004) “ Private and public sector wages in Bulgaria” J. Comparative Economics, v. 32 (1) March, 56-72.

Flanagan, Robert J. (1992) "Wages and Wage Policies in Market Economies: Lessons for Central and Eastern Europe," OECD Economic Studies, Vol. 10, No.18, Spring pp.105-32.

(1994) "Were Communists Good Human Capitalists? The Case of the Czech Republic" mimeo, Stanford, June.

Fleischer, Belton, Klara Sabrianova Peter and Xiaojun Wang (2003). "Cross Country

Comparison of the Path of returns to schooling during the early transition in Eastern Europe, the Russian Federation and China”, mimeo, Ohio State University

Giddings, Lisa A. (2003) “Continued decline for Ethnic Minorities in transition? Changes in Ethnic Earnings Differentials in Bulgaria, 1986, 1993 and 1997” Economics of transition, v. 11, \# 4, 621-48.

Gunderson, Morely (1989) "Male Female Wage Differentials and Policy Responses", $\underline{\text { Journal of }}$ Economic Literature, \# 27, March.

Heckman, James J., Lochner, Lance J. and Todd, Petra E. (2003) "Fifty years of Mincer earnings regressions”, IZA Discussion Paper, \# 775.

Heckman, James J. and Polachek, Solomon W. (1974) : Journal of the American Statistical Association v69, n346 (June): 350-54

International Labor Office (1993) The Bulgarian Labor Market, ILO, Geneva.

Jones, Derek C.,(1991) "The Bulgarian Labor Market in Transition," International Labor Review, Vol.130, No.2, 1991, pp.211-226.

(1992) "The Transformation of Labor Unions in Eastern Europe: The Case of Bulgaria" Industrial and Labor Relations Review, v.45, \# 3, April, 452-470. and Miller, Jeffrey (eds.) 1997.The Bulgarian Economy: Lessons from Reform During Early Transition Avebury. 
Jones, Derek C. and Parvulov, Svilen "Industrial Organization in a Restructuring Socialist Economy: Evidence from Bulgaria" Empirica, 1995, v. 2, pp. 23-46.

Jones, Derek C. and Charles Rock (1994) " Privatization in Bulgaria" in Privatization in Eastern and Central Europe, edited Saul Estrin, Longmans.

Kornai, Janos (1990) Economics of Shortage, Amsterdam, North Holland.

Krueger, Alan B., and Lawrence Summers (1988) " Efficiency Wages and the Inter Industry Wage Structure," Econometrica, Vol. 56, No.2 (March). pp.259-293.

Lewin, David, Daniel Mitchell and Mahmood Zaidi (eds.), (1995) Handbook of Human Resources, JAI Greenwich, Conn.

Micklewright, John. (1999) “Education, inequality and transition”, Economics of Transition; 7(2): 343-376

Munich, Daniel., Jan Svejnar and Kathy Terrell (1999) "Returns to Human Capital under the communist wage grid and during the transition to a Market economy" CEPR Discussion paper: 2332, December.

Newell, Andrew, and Reilly, Barry. (1999) "Rates of return to educational qualifications in the transitional economies” Education Economics; 7(1)

Orazem, Peter F., and Milan Vodopivec (1994) "Winners and Losers in Transition: Returns to Education, Experience and Gender in Slovenia," World Bank, Policy Research Working Paper 1342, August.

Pencavel, John (1991) Labour Markets under Trade Unionism Blackwell.

Pinto, Brian, Marek Beleva and Stefan Krajewski (1993) "Transforming State Enterprises in Poland" Brookings Papers on Economic Activity, \# 1.

Polachek, Solomon.W. and W.Stanley .Siebert (1993) The Economics of Earnings, Cambridge University Press.

Rubin, Marc (1986) "Occupation and Earnings Inequality: Some Contrasts Between Workers and Managers in Soviet Industry" Economics of Planning v 20, \#3, pp.206-30.

Rutkowski, Jan (1994) "Wage Determination in Late Socialism: The Case of Poland" Economics of Planning, v. 27, 135-164. 
Sziraczki, Gyorgy and James Windell, (1992) "Impact of Employment Restructuring on Disadvantaged Groups in Hungary and Bulgaria", International Labor Review, Vol. 131, No. 45, pp.471-497.

Svejnar, Jan (1993) "Labor Market Adjustment in Transitional Economies" Proceedings of the World Bank Annual Conference on Development Economics, 1992, 157-168

1999. "Labor Markets in the Transitional Central and East European Economies"

Handbook of Labor Economics, Volume 3, edited by O. Ashenfelter and D. Card, 2809-2857

World Bank (2 vols.) (1992) Bulgaria, Crisis and Transition to a Market Economy, The World Bank, Washington, D.C. 


\section{$\underline{\text { Endnotes }}$}

${ }^{1}$ Many studies of early transition are able to address only selected issues of income determination, notably the role played by differences in human capital, only by including data at enterprise or industry level (e.g. Flanagan, 1994; Rutkowski, 1994). In such studies, no account has been able to be taken of those dimensions of individual worker quality whose patterns likely vary within firms and which also are apt to have changed during the turbulent times of early transition. When researchers have data for individuals, the focus is almost exclusively on human capital variables. But during transition non-competitive forces may be manifested in individual attributes that normally are not associated with individual productivity. When data on these exogenous factors are available, typically they are for features beyond individual firms (e.g. industry dummies, as in Orazem and Vodopivec, 1994). When available, data on firm characteristics are quite limited (e.g. Bird et al., 1994).

${ }^{2}$ In all specifications that follow, we estimated the models by allowing for an arbitrary variancecovariance structure among the error terms on multiple observations on the same individual (person level clustering), as well as by using person random effects. In almost all cases, the results were virtually the same. Exceptions are noted below.

${ }^{3}$ Institutionally, while the essential features of wage determination were essentially unchanged from the classic Soviet type system, by 1989 there were some minor ways in which the Bulgarian situation differed from the classical STE. For example, a system of "workers management" had been introduced, including in 1989 the possibility of employee representation on boards of directors of firms.

${ }^{4}$ Since most firms are single establishment, for ease of exposition we use "firm" and "establishment" interchangeably (even though there are some cases in which a firm has multiple establishments.)

${ }^{5}$ About $20 \%$ of Bulgarian workers had a college education.

${ }^{6}$ To check our linearity assumption about the impact of education, we also estimated models in which we make use of four educational categories. For the whole period we find that $\mathrm{F}$ tests reject the hypothesis that the variables in the educational vector are jointly significant. Individual coefficients are also strongly statistically significant. Relative to a base case of more than 15 years of education, workers with $0-8$ years of education earn $24 \%$ less, while the corresponding numbers for $9-12$ and $13-14$ years of education are $18 \%$ and $14 \%$ respectively. Thus these findings provide support for our assumption of linearity with returns averaging about $4 \%$ per year..

7 As we report below in footnote 14, we also estimated models that use other measures of labor market experience. However, in a context of low labor turnover, we expect that firm specific and total (true) experience measures will be highly and positively correlated. 
${ }^{8}$ These results from models with person random effects are available from the authors upon request, as are findings for all other unreported models presented in this paper.

${ }^{9}$ We use Chow tests to choose preferred specifications across sets of regressions.

${ }^{10}$ In earlier work we also examined for the role of other factors, including occupation. However we are persuaded by an anonymous referee that it is appropriate to omit such factors for the purpose of this paper.

${ }^{11}$ In unreported regressions we use value added per worker. These estimates indicate that findings are essentially insensitive to the choice of measure for firm performance.

12 Specifically $3.38 \%$ of the respondents had been in the firm 1 year and $2.97 \%$ had been there for 2 years. Moreover, of those who had been at their place of work for 2 years or less, the bulk were new workers who had not changed jobs. Thus, selectivity does not appear to be a problem, and OLS estimation methods are appropriate in this context.

13 The difference in results from models that use these as opposed to person random effects is negligible.

14 We also estimated this baseline model using age and its square to capture experience (rather then our reported measure of potential experience.) In these estimates neither age coefficient was statistically significant though an F test on the joint significance of the experience variables (measured by age and age square) rejects the hypothesis that experience does not affect wage determination.

${ }^{15}$ We also estimated this baseline model for the whole period adding employer-specific experience and its square to capture tenure with that employer as well as the reported measure of total labor market experience. Reassuringly the addition of these variables has no marked effect of returns to education (which are now estimated at 3.8\% for each year of education.) though the returns to general labor market experience do fall a little. One of the employer-specific experience coefficients is statistically significant though an F test on the joint significance of the two variables accepts the hypothesis that tenure does not affect wage determination.

16 The F statistics that reject the hypothesis that preferred specifications are baseline models are 21.4 and 14.6 for models 3a and 3b respectively.

${ }^{17}$ Tests on the joint significance of the additional individual variables generate the following $\mathrm{F}$ statistics: model 3a, 45.8 and model 3b, 14.6.

${ }^{18}$ For model 3a the F statistic is 2.14 (probability > F: 0.073) while for model 3b the F statistic is 5.203 .

${ }^{19}$ In unreported regressions we estimated a similar model except that enterprise performance was measured by value added per worker (where value added is income from sales minus material 
costs.) The results from are essentially comparable to those obtained when using profits to capture performance though the impact of this measure of performance on earnings was not substantially different in either period.

${ }^{20}$ For example, Falarin (2004) finds that in Bulgaria ownership plays a large role in affecting job opportunities, whereas we find that ownership does not affect wages much in Bulgaria during early transition. While these differing findings on the role of ownership may partly reflect differences in topics, the use of different measures for key variables such as education and a narrower range of explanatory variables, we suspect that a crucial factor is our using a panel of matching data rather than a single cross section.

${ }^{21}$ While studies of wage determination in Bulgaria are quite limited, other evidence tends to confirm this conjecture (and does so by using data for more recent years.) See, for example, Giddings (2002).

22 Compared to many other countries (including the Visegrad 4), Bulgaria suffered the largest drop in output during this period, the most severe drop in employment, the biggest fall in real wages and the fastest rise in unemployment (EBRD, 94). Arguably in such conditions a convergence hypothesis would lead one to expect that human capital factors should have driven wages the most. 